\title{
Financial Report, Corporate Governance According to the Report on the Observance of Standards and Codes on Accounting and Auditing
}

\author{
Assoc Prof. Ylber BEZO, \\ College University of Business Tirana Albania,Vangjel Noti,Tirane \\ Ph.D.Rezart DIBRA, \\ College University of Business Tirana Albania,Vangjel Noti,Tirane
}

\begin{abstract}
Albania has a new economy. After the communist regime, Albania has adopt the new standard of accounting. In this period Albanian companies is focused in respecting of financial standards and applied of standards accounting. In this way all the Albanian company has adopt their standards of accounting. A lot of company has adopt their code of corporate governance. Albania has a lot of to do about corporate governance. Albania's remarkable economic transformation has been affected by the global financial crisis. The country's main challenges include maintaining macro-fiscal and financial sector sustainability, improving the investment climate and unleashing private sector growth, removing barriers to employment for job creation, and improving governance and public service delivery. Improving the business climate and addressing gaps in infrastructure and labor force skills are necessary to reap the early benefits of European Union (EU) accession and make Albania attractive for foreign direct investments. The revised Conceptual Framework for Financial Reporting (Conceptual Framework) issued in March 2018 is effective immediately for the International Accounting Standards Board (Board) and the IFRS Interpretations Committee. For companies that use the Conceptual Framework to develop accounting policies when no IFRS Standard applies to a particular transaction, the revised Conceptual Framework is effective for annual reporting periods beginning on or after 1 January 2020, with earlier application permitted.

This paper is contain some elements of standards in accounting and some aspect of corporate governance, concretely based on the model of business today.

Keywords: Financial Report, Corporate governance, Accounting Standards etc.

DOI: $10.7176 /$ RJFA/11-17-09

Publication date:October $31^{\text {st }} 2020$

\section{ACCOUNTING \& AUDITING STANDARDS}

The accountancy profession promotes, develops and supports accountants worldwide. Their role is crucial in protecting the quality and integrity of accountants who are core to the rigorous application of the Standards. Accounting profession is adopt from a lot of preson that has pas an exam but the professions are few very few persons. Beneish and Yohn (2008) evaluating if the IFRS adoption reduces the information processing costs, the investor uncertainty about the financial reporting quality or uncertainty about the distribution of future cash flows, verified that the national determinants, such as investor protection mechanisms, national trends of family shareholders, are stronger than IFRS adoption. In this study, the authors conclude that the global adoption is unlikely to affect local trends (Journal of Business \& Economic Policy Vol. 2, No. 2; June 2015). The quality of financial reporting depends to a great extent on the quality of the accounting and auditing standards on which the reporting is based. Countries that are seeking to improve their business environment, improve access to finance, and attract foreign direct investment need good national accounting standards that provide transparent and accurate financial information. The ROSC A\&A assessment of accounting and auditing standards seeks to compare national financial reporting with good international practice to give a clear sense of key areas of divergence and identify potential or actual problems and issues.
\end{abstract}

\section{GENERAL FINANCIAL REPORTING REQUIREMENTS}

The Conceptual Framework sets out the fundamental concepts for financial reporting that guide the Board in developing IFRS Standards. It helps to ensure that the Standards are conceptually consistent and that similar transactions are treated the same way, so as to provide useful information for investors, lenders and other creditors. The Conceptual Framework also assists companies in developing accounting policies when no IFRS Standard applies to a particular transaction, and more broadly, helps stakeholders to understand and interpret the Standards The general financial reporting and auditing requirements for the corporate sector are contained in various laws and regulations. Further detail on Limited Liability Companies are in the table below : 
Table : 1 . Accounting in LLC.

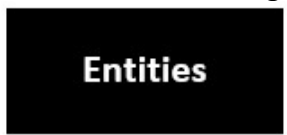

\section{Accounting} Standards

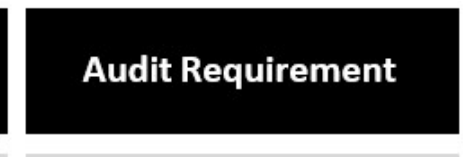

Limited

liability companies

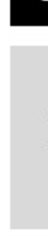

\section{Required for companies \\ that fit the criteria}

Public Disclosure

Required for medium and

large sized companies and

PIEs

\section{THE MODELS OF BUSINESS}

There are three models of business governance:

1. Shareholder Model of Business Governance

2. The model of business governance by interest groups

3. The model of social responsibility of business governance.

1. Shareholder model of business governance

This model operates on the basis of the basic premise that the purpose of the business is to maximize the financial income of its owners, or in the case of corporations, of its shareholders.

According to prominent economist Milton Friedman, the role of corporate employees is simply to make as much money as possible for their shareholders.

Of course, many other groups of individuals (and society as a whole) can benefit from running a successful business (community collects property taxes, suppliers are paid, employees are paid, etc.) but primarily at this level of government, the corporation exists for profit. of its shareholders.

Separation of ownership and control, potential conflicts of interest

In most corporations today, there is a separation of ownership and control. Corporate ownership is in the hands of hundreds of thousands of shareholders scattered everywhere. Everyone owns a small part of the business.

While control of the corporation rests with the board of directors and perhaps even more so with its officials.

There are a number of key areas where there are potentially significant shareholder-official conflicts. These conflicts are:

1. Control offer (offer to buy)

2. Short-term orientation / long-term orientation

3. Empire building (Company growth)

4. Access to information

Officials and directors are agents who report to its shareholders, while the fragmented nature of most corporate holdings today gives shareholders little monitoring power over corporate directors and officers.

In many cases, corporate officials and directors act more in their own interest than in the best interest of the leaders, the shareholders.

Control offers (offers to be purchased)

Mergers and acquisitions are a regular part of corporate life. If a company receives an offer to buy from another company at $50 \%$ more than the current price of its shares, for the shareholders of the company to be bought, it is something wonderful, but not for the officials who may risk and job. So corporate officials and directors may be less willing than the average shareholder to welcome control bids, thus creating potential conflict of interest.

Control offers (offers to be purchased)

Mergers and acquisitions are a regular part of corporate life. If a company receives an offer to buy from another company at $50 \%$ more than the current price of its shares, for the shareholders of the company to be bought, it is something wonderful, but not for the officials who may risk and job. So corporate officials and directors may be less willing than the average shareholder to welcome control bids, thus creating potential conflict of interest.

\section{Short-term versus long-term orientation}

Investors often have a long-term orientation, while many corporate officials are criticized for short-term orientation. Shareholders may intend to own the shares of quality companies for decades. As a result, they may not be particularly concerned about the company's current profitability

Long-term investors want the company to invest in new products and in research and development (R\&D), while officials who plan to leave after 2-3 years, seek the current maximum profit, so try to reduce the budget for 
Research - Development.

3. Empire Building (Company Growth)

Managers are often interested in expanding their business, because many directors and officers are paid according to the size of the business they run.

While building empire is good for the company's executives, it is not always good in the long run for its shareholders. corporations are not geared etc.)

4. Access to Information

Company executives know for sure, or practically need to know everything that happens in the corporation. Shareholders are invited to attend the corporation's annual meetings (but in fact, only a small number attend).

What does this asymmetry of corporate information bring?

A general manager who knows good news about the corporation can go and buy shares from an existing shareholder, who may not sell them if he had the information that the corporate leader has and vice versa.

Resolving conflicts of interest

There are two types of options for resolving some of the conflicts of interest due to segregation ownership and control.

1. Private solutions

2. Public or governmental solutions

2. The model of business governance by interest groups

Otherwise known as the Stakeholders model of business governance.

According to Blackwell and other proponents of this model, businesses exist for the benefit not only of shareholders, but also of various groups that have a significant interest in their activities.

Coca-Cola is one of the companies that has formally adopted the corporate governance model by stakeholders.

On its website, it has an official statement stating that "The Coca - Cola Company is fundamentally built on the deep and enduring relationship of trust between her and all individuals such as: bottler, customers, consumers, shareholders, employees, suppliers, and the community itself. This belief must be nurtured and maintained daily.

- Businesses and the local community

Many companies today make special efforts to judge the impact of its business activities on the local communities where it trades. For example, oil companies undertake consultations with local groups in planning new oil drilling projects.

Before building a new pipeline in the Philippines, the company consulted extensively with local groups about the pipeline route. Also, the pipeline was carefully laid to avoid places of historical value, coral reefs and fishing areas.

Some companies give percentages of sales to the local community where they do business. Other firms focus on art and culture, perhaps sponsoring local symphony or ballet troupes. Others develop children's reading programs by providing books, etc.

Many companies operating around the world change their community activities depending on where they operate.

- Creditors

What responsibilities do businesses have towards the individuals and institutions from which they borrow money? People who lend to corporations have the right to be treated as important shareholders.

- Suppliers

Companies such as Coca-Cola view suppliers as an important interest group, and carefully manage relationships with this group, keeping them informed of future plans and negotiating prices and delivery times with them.

\section{5 .CONCLUSION}

Adopting of corporate governance standards and accouting standards is very important. Overall, this analysis allows inferring that the accounting quality cannot be evaluated only in terms of IFRS adoption, either on a voluntary or mandatory basis. More recently, Ahmed et al. (2013) also verified that accounting quality declined after mandatory adoption of IFRS, unlike previous studies have shown, highlighting an increase in the accounting quality after IFRS adoption. Albania company in the future has a lot to do about corporate governance.

\section{REFERENCES}

1.Ahmed, A. S., Neel, M., \& Wang, D. (2013). Does Mandatory Adoption of IFRS Improve Accounting Quality? Preliminary Evidence. Contemporary Accounting Research, 30(No. 4), 1344-1372. doi: 10.1111/j.1911- 
3846.2012.01193.x

2.Aljifri, K., \& Khasharmeh, H. (2006). An investigation into the suitability of the international accounting standards to the United Arab Emirates environment. International Business Review, 15(5), 505-526. doi: 10.1016/j.ibusrev.2006.05.009

3.Armstrong, C. S., Barth, M. E., Jagolinzer, A. D., \& Riedl, E. J. (2010). Market Reaction to the Adoption of IFRS in Europe. Accounting Review, 85(1), 31-61. doi: 10.2308/accr.2010.85.1.31

4.Albania - ROSC Accounting \& Auditing. http/worldbank.org/en.

5.Lopes, A. B. (2009). Normas internacionais de contabilidade. In J. F. R. Filho, J. Lopes \& M. Pederneiras (Eds.), Estudando teoria da contabilidade. Atlas.

6. https://www.ifrs.org/issued-standards/list-of-standards/conceptual-frame

7.In search of good directors. A project of The central European University Foundation and The Center for International Private Enterprise,1998.CIPE. 